\title{
An Analysis of Process Type Used in News Item
}

\author{
Achmad Yudi Wahyudin \\ achmad.yudi@teknokrat.ac.id \\ STBA Teknokrat
}

\begin{abstract}
Since the educational curriculum for English subject in Indonesia is implemented around genres, news item has been one of the genres taught in secondary school in Indonesia. Understanding the authors' points of view and intention will contribute significant implication for learning foreign language $(F L)$. One of the ways of analyzing one's experience in written language is by using systemic functional grammar (SFG) theory. Therefore, this article aims at providing SFG analysis of process type used on news item. The news item was selected from Jakarta Post, 2014 in which one article entitled 72\% of Indonesian people agree with nuclear power plants was selected and analyzed by categorizing its experiential meaning (Gerot \& Wignel, 1995). The analysis portrayed the dominance of verbal process existed in the article and it mainly indicate an effective news item.
\end{abstract}

Key Words: news item, process type, SFL

\section{Introduction}

In the study of SFG, there has been much discussion on how transitivity analysis used to interpret one's experiential process. Transitivity system represents the world of experience into a manageable set of process type (Eggins, 2004). Transitivity represents the encoding of experiential meanings: meaning about the world, about experience, about what we perceive and experience what is going on (Halliday, 1994). It can be said that, the experiential meaning deals with people's perception of the world by using language. The people's experience of reality is captured in terms of processes such as happening, doing, sensing, meaning, being, and becoming. These processes constitute the transitivity system of language, which belongs to the experiential metafunction. In transitivity analysis, then, we explore how language construes our experience of the world around us.

Further, there are several types of process identified in transitivity. These types are material, behavioral, mental, verbal, relational, and existential. A material process refers to a process of doing or happening, and the actor is the key participant. A material process can be confirmed by asking "what did the Actor do?" or "what happened?" (Butt et al, 2000). The mental process deals with affection, cognition, perception, or desideration (Halliday \& Matthiesen, 2004). Verbal processes include all modes of expressing and indicating, even if they are not verbal, such as "showing". Relational process refers to a process that expresses state of being. According to Halliday and Matthiessen (2004), a relational clause serves to characterize and identify. Existential processes represent experience by positing that "there was/is something" (Eggins, 2004 cited in Emilia, 2014). By examining transitivity patterns in text, we can explain how the field of situation is being constructed. In a simple way, transitivity is the study of what people doing by which mainly discussed who does what to whom (Mayr \& Machin, 2012).

Several studies have been conducted to explore transitivity system used in various genres as the way to express experiential meaning. Afrianto \& Zuhud (2014) attempted to explore mental and relational process in poems. The result indicates that the word love, honor, know, think, hear, see, repent, mind, want, fear, and dream become the verbs that represent mental process and contribute to the experiential meaning. In addition, Kuswoyo (2013) examined the transitivity system that exists on the literary work. This study is mainly concerned with the most frequent perception words used by the writer in the novel of Pride and Prejudice. It was found that the words see, watch, hear, listen, feel, observe, touch, and stare at are the most frequent words that appear on the novel. Ong'onda (2016) conducted an analysis of newspaper headlines on terrorism attack in Kenya and the study found that material and relational processes dominate the other processes that indicate the whole process of terrorism is concerned with events and actions. The findings also show that the grammatical choices in newspaper reports played a role to covertly express the writers' perspectives towards certain Islamic community, which affects the readers' opinion making process.

The three studies above have confirmed that transitivity system gives significant contribution to understand the writer's intention of using language on certain genres. This study attempted to replicate the previous studies in different context. One of the texts that can be found by us daily and everyone might encounter is news 
item. News item also become the main text taught in secondary education in Indonesia. Analysing the news item may give valuable insight to the learner so that they can experience the language from different kind of topics existing on news item. This may also help the EFL learners in Indonesia to learn English better. Since news item tells about what was going on, it must consist of several process types. However, not all news item is constructed by appropriate process types and meet the criteria of good news item (see Gerot \& Wignel, 1995). Therefore it is necessary to analyze the news item to explore how it is constructed and to determine the quality of the news item circulated around the community.

\section{Theory and Method}

The analysis used in this study mainly was based on the principle of SFG established by Halliday (1994); Halliday \& Matthiesen (2004); and Gerot \& Wignell (1994), and Eggins (2004). The sample of news item analysed in this study was posted in The Jakarta Post entitled $72 \%$ of Indonesian people agree with nuclear power plants. This news item which talks about Indonesian people perspective towards the government's plan to develop nuclear power plant. The analysis used in this study mainly was based on the principle of SFG established by Halliday (1994); Halliday \& Matthiesen (2004); and Gerot \& Wignell (1994), and Eggins (2004). The procedure of analysis involve: (1) collecting the document, (2) labeling words and clauses, (3) Counting the most frequent words appear on the text. In this study, two research assistants were required to double-check and review the process of analysis so that the findings might be accurate and credible. The text below is the news item analyzed in this study.

\section{$\mathbf{7 2 \%}$ of Indonesian people agree with nuclear power plants}

Results of a poll commissioned by an independent survey agency reveal that 72 percent of Indonesian people agree with the government's plan to develop nuclear power plants (PLTN).

"Nationally, the percentage of people who can accept PLTN reaches 72 percent, while in Bali, Java and Madure, those who can accept them reaches 74 percent," National Nuclear Energy Agency (BATAN) head Djarot Wisnubroto said, as quoted by Antara news agency in Jakarta on Tuesday.

He further said that according to the survey's results, 57 percent of people in Bangka Belitung could accept PLTN development.

The survey conducted by pollster PT Media Cipta Pesona involved 3,000 respondents nationally, 1,000 respondents in Bali, Java and Madura and 1,000 respondents in Bangka and Belitung. The survey, which ran from October through November, used a random sampling method with an error margin of 1.8 percent.

Djarot said the latest survey showed greater public support than the two previous studies, in which only 52.9 percent of respondents agreed with PLTN development in 2012 and 60.4 percent in 2013.

"In 2011, public acceptance for PLTN stood at 49.5 percent, down from 59.7 percent in 2010 because of the Fukushima Daiichi nuclear plant disaster following a major earthquake and tsunami in the area," said Djarot, adding that the survey results would be presented to President Joko "Jokowi" Widodo and related ministries. (ebf)(+++). Source: The Jakarta Post, Jakarta | National | Tue, December 16 2014, 9:06 PM

Jakarta Post was chosen as the source of news item because it is one of the most reputable newspapers in Indonesia written in English. The language used in this newspaper is considered using standard of proper English. Therefore, the result of analysis might represent the sample of effective news for serving the purpose of the study and valuable item for EFL learners to learn.

\section{Results}

The results depicted below are the representative of transitivity system that occurs on the news item. There are several processes identified on the news item entitled $72 \%$ of Indonesian people agree with nuclear power plants. They are verbal process, material process, mental process, and relational process.

\section{A. Verbal Process}

It appears that the verbal process is the most frequent process that appears on the text. The result can be seen in the following table. 
Table 1.1 Verbal Process existing on the text

\begin{tabular}{|l|l|l|l|l|l|l|}
\hline $\begin{array}{l}\text { National Nuclear Energy Agency } \\
\text { (BATAN) head Djarot Wisnubroto }\end{array}$ & Said & As & Quoted & $\begin{array}{l}\text { by Antara } \\
\text { news agency }\end{array}$ & $\begin{array}{l}\text { in } \\
\text { Jakarta }\end{array}$ \\
\hline Sayer & $\begin{array}{l}\text { Pr: } \\
\text { Verbal }\end{array}$ & & Pr: verbal & Sayer & $\begin{array}{l}\text { Circ: } \\
\text { Place }\end{array}$ \\
\hline
\end{tabular}

\begin{tabular}{|l|l|l|l|l|l|l|l|l|}
\hline He & further & Said & That & according to & $\begin{array}{l}\text { the survey's } \\
\text { result }\end{array}$ & $\begin{array}{l}\text { 57 percent } \\
\text { of people }\end{array}$ & $\begin{array}{l}\text { in Bangka } \\
\text { Belitung }\end{array}$ \\
\hline Sayer & & Pr: Verbal & & Pr: verbal & Sayer & Senser & Circ: Place \\
\hline
\end{tabular}

\begin{tabular}{|l|l|l|l|l|l|}
\hline $\begin{array}{l}\text { Results of } \\
\text { a poll }\end{array}$ & Commissioned & $\begin{array}{l}\text { by an independent survey } \\
\text { agency }\end{array}$ & reveal & that \\
\hline Goal & Process: Material & Actor & $\begin{array}{l}\text { Process: } \\
\text { verbal }\end{array}$ & \\
\hline
\end{tabular}

\begin{tabular}{|l|l|l|l|l|l|l|l|}
\hline Djarot & Said & the latest survey & Showed & $\begin{array}{l}\text { greater public } \\
\text { support }\end{array}$ & $\begin{array}{l}\text { than the two } \\
\text { previous studies }\end{array}$ \\
\hline Sayer & $\begin{array}{l}\text { Pr: } \\
\text { Verbal }\end{array}$ & Sayer & Pr: verbal & verbiage & Circ: comparison & \\
\hline
\end{tabular}

\begin{tabular}{|l|l|l|l|l|l|l|}
\hline Said & Djarot & Adding & that & $\begin{array}{l}\text { the survey } \\
\text { results }\end{array}$ & $\begin{array}{l}\text { would be } \\
\text { presented }\end{array}$ & $\begin{array}{l}\text { to Joko “Jokowi” Widodo } \\
\text { and related ministers. }\end{array}$ \\
\hline $\begin{array}{l}\text { Pr: } \\
\text { Verbal }\end{array}$ & Sayer & Pr: Verbal & & Goal & $\begin{array}{l}\text { Pr: } \\
\text { Material }\end{array}$ & Recipient \\
\hline
\end{tabular}

Based on the table above, the words used on the news item that represent verbal processes are said, according to, reveal, showed, and adding.

\section{B. Material Process}

The result of analysis point out that material process is the second most frequent process that appears on the text. The material process existing on the text can be seen in the following table.

Table 1.2 Material Process existing on the text

\begin{tabular}{|l|l|l|l|l|}
\hline $\begin{array}{l}\text { Results of } \\
\text { a poll }\end{array}$ & commissioned & $\begin{array}{l}\text { by an independent survey } \\
\text { agency }\end{array}$ & reveal & that \\
\hline Goal & Process: Material & Actor & $\begin{array}{l}\text { Process: } \\
\text { verbal }\end{array}$ & \\
\hline
\end{tabular}




\begin{tabular}{|l|l|l|l|l|l|l|l|}
\hline Said & Djarot & Adding & that & $\begin{array}{l}\text { the survey } \\
\text { results }\end{array}$ & $\begin{array}{l}\text { would be } \\
\text { presented }\end{array}$ & $\begin{array}{l}\text { to Joko “Jokowi” Widodo } \\
\text { and related ministers. }\end{array}$ \\
\hline $\begin{array}{l}\text { Pr: } \\
\text { Verbal }\end{array}$ & Sayer & Pr: Verbal & & Goal & $\begin{array}{l}\text { Pr: } \\
\text { Material }\end{array}$ & Recipient \\
\hline
\end{tabular}

\begin{tabular}{|l|l|l|l|l|}
\hline $\begin{array}{l}72 \text { percents of } \\
\text { Indonesian people }\end{array}$ & agree & $\begin{array}{l}\text { with the } \\
\text { government's plan }\end{array}$ & to develop & $\begin{array}{l}\text { Nuclear power } \\
\text { plants (PLTN). }\end{array}$ \\
\hline Senser & Pr: Mental & Circ: Matter & Pr: Material & Goal \\
\hline
\end{tabular}

\begin{tabular}{|l|l|l|l|l|}
\hline $\begin{array}{l}\text { The } \\
\text { survey }\end{array}$ & conducted & $\begin{array}{l}\text { by pollster PT Media Cipta } \\
\text { Pesona }\end{array}$ & involved & 3000 respondents \\
\hline Goal & Pr: Material & Actor & Pr: attributive & Attribute \\
\hline
\end{tabular}

\begin{tabular}{|l|l|l|l|l|l|l|}
\hline $\begin{array}{l}\text { The } \\
\text { survey }\end{array}$ & which & ran & $\begin{array}{l}\text { from October } \\
\text { through } \\
\text { November }\end{array}$ & used & $\begin{array}{l}\text { a random } \\
\text { sampling method }\end{array}$ & $\begin{array}{l}\text { with an error } \\
\text { margin of } 1.8 \\
\text { percent }\end{array}$ \\
\hline Actor & & $\begin{array}{l}\text { Pr: } \\
\text { Material }\end{array}$ & Cir: extent & $\begin{array}{l}\text { Pr: } \\
\text { material }\end{array}$ & Goal & Cir: manner \\
\hline
\end{tabular}

\begin{tabular}{|l|l|l|l|}
\hline $\begin{array}{l}\text { Because of The Fukushima Daichi nuclear } \\
\text { plant disaster }\end{array}$ & following & $\begin{array}{l}\text { a major earthquake } \\
\text { and Tsunami }\end{array}$ & in the area \\
\hline Circ: Cause & Pr: material & Goal & $\begin{array}{l}\text { Circ: } \\
\text { location }\end{array}$ \\
\hline
\end{tabular}

Based on the table above, the words used on the news item that represent material processes include commissioned, presented, develop, conducted, rand, used and following.

\section{Mental Process}

The mental processes are the third process that appears on the text as the representative of experiential meaning. The mental processes can be seen in the following table.

Table 1.3 Mental Process existing on the text

\begin{tabular}{|l|l|l|l|l|l|l|l|l|l|}
\hline Nationally, & $\begin{array}{l}\text { the } \\
\text { percentag } \\
\text { e of people }\end{array}$ & Who & $\begin{array}{l}\text { can } \\
\text { accept }\end{array}$ & PLTN & reaches & $\begin{array}{l}72 \\
\text { percent }\end{array}$ & while & $\begin{array}{l}\text { in } \\
\text { Bali }\end{array}$ \\
\hline $\begin{array}{l}\text { Circ: } \\
\text { manner }\end{array}$ & Senser & & $\begin{array}{l}\text { Pr: } \\
\text { Mental }\end{array}$ & $\begin{array}{l}\text { Pheno } \\
\text { menon }\end{array}$ & $\begin{array}{l}\text { Pr: } \\
\text { attributive }\end{array}$ & Attribute & & $\begin{array}{l}\text { Circ: } \\
\text { Place }\end{array}$ \\
\hline
\end{tabular}




\begin{tabular}{|l|l|l|l|l|l|l|l|}
\hline $\begin{array}{l}\text { Java and } \\
\text { Madure }\end{array}$ & Those & Who & can accept & them & reaches & 74 percent \\
\hline Circ: Place & Senser & & Pr: Mental & Phenomenon & Pr: attributive & Attribute & \\
\hline
\end{tabular}

\begin{tabular}{|l|l|l|l|l|l|l|l|}
\hline Which & $\begin{array}{l}\text { only 52.9 } \\
\text { percent of } \\
\text { respondents }\end{array}$ & agreed & $\begin{array}{l}\text { with PLTN } \\
\text { development }\end{array}$ & in 2012 & and & $\begin{array}{l}60,4 \\
\text { percent }\end{array}$ & in 2013 \\
\hline & Senser & Pr: mental & Circ: matter & $\begin{array}{l}\text { Circ: } \\
\text { time }\end{array}$ & & Senser & Circ: time \\
\hline
\end{tabular}

\begin{tabular}{|l|l|l|l|l|}
\hline $\begin{array}{l}\text { 72 percents of } \\
\text { Indonesian people }\end{array}$ & agree & $\begin{array}{l}\text { with the } \\
\text { government's plan }\end{array}$ & to develop & $\begin{array}{l}\text { Nuclear power } \\
\text { plants (PLTN). }\end{array}$ \\
\hline Senser & Pr: Mental & Circ: Matter & Pr: Material & Goal \\
\hline
\end{tabular}

\begin{tabular}{|l|l|}
\hline Could accept & PLTN development \\
\hline Pr: Mental & Phenomenon \\
\hline
\end{tabular}

The table above suggested that the words used on the news item that represent mental processes include accept and agree.

\section{Relational Process}

The mental processes are the third process that appears on the text as the representative of experiential meaning. The mental processes can be seen in the following table.

\begin{tabular}{|l|l|l|l|l|}
\hline Nationally, & $\begin{array}{l}1000 \\
\text { respondents }\end{array}$ & $\begin{array}{l}\text { in Bali, Java and } \\
\text { Madura }\end{array}$ & 1000 respondents & in Bangka and Belitung \\
\hline Cir: manner & Attribute & Cir: location & Attribute & Cir: location \\
\hline
\end{tabular}

\begin{tabular}{|l|l|l|l|l|l|l|}
\hline In 2011 & $\begin{array}{l}\text { public acceptance } \\
\text { for PLTN }\end{array}$ & stood & $\begin{array}{l}\text { at 49,5 } \\
\text { percent }\end{array}$ & down & from 59,7 percent & in 2010 \\
\hline $\begin{array}{l}\text { Circ: } \\
\text { time }\end{array}$ & Carrier & $\begin{array}{l}\text { Pr: } \\
\text { attributive }\end{array}$ & Attribute & & Cir: location & Cir: Time \\
\hline
\end{tabular}

\begin{tabular}{|l|l|l|l|l|l|l|l|l|l|}
\hline Nationally, & $\begin{array}{l}\text { the } \\
\text { percentag } \\
\text { e of } \\
\text { people }\end{array}$ & Who & $\begin{array}{l}\text { can } \\
\text { accept }\end{array}$ & PLTN & reaches & $\begin{array}{l}72 \\
\text { percent }\end{array}$ & while & $\begin{array}{l}\text { in } \\
\text { Bali }\end{array}$ \\
\hline
\end{tabular}




\begin{tabular}{|l|l|l|l|l|l|l|l|l|}
\hline $\begin{array}{l}\text { Circ: } \\
\text { manner }\end{array}$ & Senser & $\begin{array}{l}\text { Pr: } \\
\text { Mental }\end{array}$ & $\begin{array}{l}\text { Pheno } \\
\text { menon }\end{array}$ & $\begin{array}{l}\text { Pr: } \\
\text { attributive }\end{array}$ & Attribute & $\begin{array}{l}\text { Circ: } \\
\text { Place }\end{array}$ \\
\hline
\end{tabular}

\begin{tabular}{|l|l|l|l|l|l|l|l|}
\hline $\begin{array}{l}\text { Java and } \\
\text { Madure }\end{array}$ & those & who & can accept & them & reaches & 74 percent \\
\hline Circ: Place & Senser & & Pr: Mental & Phenomenon & Pr: attributive & Attribute \\
\hline
\end{tabular}

\begin{tabular}{|l|l|l|l|l|}
\hline $\begin{array}{l}\text { The } \\
\text { survey }\end{array}$ & conducted & $\begin{array}{l}\text { by pollster PT Media Cipta } \\
\text { Pesona }\end{array}$ & involved & 3000 respondents \\
\hline Goal & Pr: Material & Actor & Pr: attributive & Attribute \\
\hline
\end{tabular}

In reference to the table above, it is suggested that the words used on the news item that represent relational processes include stood, reach and involve.

\section{Discussion}

An analysis on transitivity from the text entitled " $72 \%$ of Indonesian people agree with nuclear power plants" shows that the text consists of four types of process, material (7), mental process (5), verbal process (9), and relational process (4); and it has no existential and behavioral process. In summary, the transitivity system depicted on the text is represented by the processes below.

Table 1. Process Types used in the news item

\begin{tabular}{|l|l|}
\hline Process type & Total \\
\hline Material & 7 \\
\hline Mental & 5 \\
\hline Verbal & 9 \\
\hline Behavioral & 0 \\
\hline Existential & 0 \\
\hline Relational & 4 \\
\hline
\end{tabular}

By looking at the process types that constructs the text above, there are some interpretations that we can derive as follows:

1. Since the most dominant process type that occurs in the text is verbal process (e.g., said, quoted, showed, etc.), it seems that the writer is trying to persuade the reader by including some quotations from the important person (National Nuclear Energy Agency (BATAN) head Djarot Wisnubroto) who is in charge of the project being talked. The presence of this sayer may constitute and emerging attempt to construe the representation which can promote the credibility and accuracy of the news (Gerot \& Wignell, 1995). By adding the result of several studies in the text, the writer attempts to convince the reader and it may lead the public opinion to agree the project of nuclear plant.

2. The second dominant process type appears in the text is material. This is very common in news item. Material process (e.g., commissioned, conducted, ran, etc.) is used to describe what has happened and to build information on the issue being pondered.

3. The third is mental process. Similar to verbal process, this mental process is mainly used to support the writer's attempt to persuade the readers.

4. The last is relational process which involves attributions such as giving the additional information related to the studies (e.g., 74 percent, 3000 respondents and 1000 respondents) that are also representational meaning. 
Apart from the process types appeared in the text above, there are several circumstances included such as cause (e.g., because of the Fukushima Daichi nuclear plant disaster), location (e.g., in Bangka Belitung, in Java and Madure), time (e.g., in 2013, in 2010), extent (e.g., from October through November), and manner (e.g., nationally) that can add significant experiential information. Those are the components that add experiential meaning (Eggins, 2004). The findings of this study somehow corresponds to the study conducted by Ong'onda (2016) in which material process becomes one of the most frequent process appear on the text since the content of the article deals with actions and events.

In sum, regardless all the intention and meaning constructed by the writer in this text, the text corresponds the criteria of good news item proposed by Gerot and Wignell (1995). The news should consist of the use of material process to retell the event and verbal process which represent the sources of the text.

\section{Conclusion}

The news item entitled " $\mathbf{7 2 \%}$ of Indonesian people agree with nuclear power plants" consists of verbal process (9), material process (7), mental process (5), and relational process (4). Verbal process becomes the most dominant process type appear in the text. This might be due to the writer's intention (apart from to inform particular issue) to persuade the readers to agree with the nuclear project. Even though this news item is only a half paragraph in length, this text is constructed by rich experiential information since it also includes several circumstantial elements that add to the representational meaning on the text.

\section{Suggestion and Implication}

Since the analysis in this study was mainly based on one article of Jakarta post, further study may analyze more than one news item so that the result can be more transferrable and confirm the finding of the present study. It is also suggested that further studies might try to analyze different genres for EFL context. The finding of the study may also give insight for learners to learn how news item is constructed so that they can learn English more effectively. The practitioner might also get benefit from the information of how the news item is made by the writer since they might spend more time and focus to teach students the processes.

\section{Acknowledgement}

Special credit goes to Ahmad Affandi and Ivone Susan who support the accomplishment of the analysis and the writing of the report.

\section{References}

Afrianto, Afrianto \& Zuhud, Dudi A. (2014). Mental and Relational Process of Transitivity in Donne's and Blake's Poems: A Systemic Functional Linguistics Approach . International Journal of English and Education 3 (2). pp.1-9.

Butt, David, 1950- \& National Centre for English Language Teaching and Research (Australia) (2000). Using functional grammar : an explorer's guide (2nd ed). National Centre for English Language Teaching and Research, Macquarie University, Sydney

Eggins, Suzanne. (2004). Introduction to Systemic Functional Linguistics. ( $2^{\text {nd }}$ Edition). Bloomsbury Academic.

Emilia, E. (2014). Introducing Functional Grammar. Bandung: Pustaka Jaya.

Gerot, Linda \& Wignell, Peter. (1995). Making Sense of Functional Grammar. Sydney: Stabler.

Halliday M.A.K. (1994). An Introduction to Functional Grammar. London: Arnold.

Halliday, M.A.K.., \& Matthiessen, Christian M.I.M. (2004). An Introduction to Functional Grammar. ( ${ }^{\text {rd }}$ Edition). London: Arnold.

Jakarta Post. (2014). $72 \%$ of Indonesian people agree with nuclear power plants. Retrieved at https//jakartapost.com on Tuesday, December 16 2014, 9:06 PM 
Kuswoyo, Heri. (2014). A systemic functional grammar analysis: Perception verbs as found in Jane Austen's Pride and Prejudice. The $1^{\text {st }}$ International Seminar on Linguistics (ISOL-I). pp. 142-150.

Mayr, Andrea \& Machin, David Ph. D (2012). The language of crime and deviance: an introduction to critical linguistic analysis in media and popular culture. Continuum, London; New York

Ong'onda, N.A. (2016). Transitivity Analysis of Newspaper Headlines on Terrorism Attack in Kenya: A Case Study of Westgate Mall, Nairobi. International Journal of Humanities and Social Science 6 (9). pp. 7785. 